\title{
Updates to the Marine Algal Flora of the Boulder Patch in the Beaufort Sea off Northern Alaska as Revealed by DNA Barcoding
}

\author{
Trevor T. Bringloe, ${ }^{1,2}$ Kenneth H. Dunton ${ }^{3}$ and Gary W. Saunders ${ }^{1}$
}

(Received 8 May 2017; accepted in revised form 19 July 2017)

\begin{abstract}
Since its discovery four decades ago, the Boulder Patch kelp bed community in the Beaufort Sea has been an important site for long-term ecological studies in northern Arctic Alaska. Given the difficulties associated with identifying species of marine algae on the basis of morphology, we sought to DNA barcode a portion of the flora from the area and update a recently published species list. Genetic data were generated for 20 species in the area. Fifty-five percent of the barcoded flora confirmed the morphological species identifications. Five barcoded species revealed what are likely misapplied names to the Boulder Patch flora; the updated names include Ahnfeltia borealis, Phycodrys fimbriata, Pylaiella washingtoniensis, Rhodomela lycopodioides f. flagellaris, and Ulva prolifera. The remaining four species require taxonomic work and possibly represent new records for the Boulder Patch. Our observations indicate that we need considerably more research to understand marine macroalgal biodiversity in the Arctic. Supplementing Arctic species lists using genetic data will be essential in establishing an accurate and reliable baseline for monitoring changes in ecosystem biodiversity driven by long-term changes in regional climate.
\end{abstract}

Key words: Arctic benthic algae; Alaskan Beaufort Sea; DNA barcoding; Boulder Patch

RÉSUMÉ. Depuis sa découverte il y a quatre décennies, le peuplement d'algues brunes de la Boulder Patch dans la mer de Beaufort représente un site important pour les études écologiques à long terme dans l'Extrême-Arctique, en Alaska. Étant donné les difficultés liées à l'identification des espèces d'algues marines en fonction de leur morphologie, nous avons cherché à effectuer le codage à barres de l'ADN d'une partie de la flore de la région et avons mis à jour une liste d'espèces récemment publiée. Des données génétiques ont été produites pour 20 espèces de la région. Les identifications morphologiques ont été confirmées dans le cas de $55 \%$ des espèces de la flore dont le code à barres a été établi. Pour cinq espèces dont le code à barres a été généré, nous avons constaté que des noms erronés avaient probablement été attribués à la flore de la Boulder Patch. Les noms à jour sont les suivants : Ahnfeltia borealis, Phycodrys fimbriata, Pylaiella washingtoniensis, Rhodomela lycopodioides f. flagellaris et Ulva prolifera. Les quatre autres espèces nécessitent une classification taxonomique et représentent peut-être de nouveaux signalements d'espèces pour la Boulder Patch. Nos observations indiquent que beaucoup d'autres recherches sont nécessaires pour comprendre la biodiversité des macroalgues marines de l'Arctique. Il sera essentiel de compléter les listes des espèces de l'Arctique à l'aide de données génétiques pour établir des données de base précises et fiables afin de surveiller les changements dans la biodiversité de l'écosystème causés par des changements à long terme du climat régional.

Mots clés : algues benthiques de l'Arctique; eaux alaskiennes de la mer de Beaufort; codage à barres de l'ADN; Boulder Patch

Traduit pour la revue Arctic par Nicole Giguère.

\section{INTRODUCTION}

The Boulder Patch kelp bed community of the Beaufort Sea lies in Stefansson Sound off the northern coast of Alaska. The boulders and cobbles are part of a Quaternary deposit that is unique to the Beaufort Sea inner shelf, which is otherwise composed of silty clays and mud in relatively shallow water $(4-7 \mathrm{~m})$ that is estuarine in character (Dunton et al., 1982). The surprising faunal and floral diversity of the Boulder Patch, in concert with its relative isolation, has attracted scientific interest since its discovery by geologists in the mid 1970s (Reimnitz and Ross, 1979). Subsequent ecological studies have focused on gaining an understanding of the community and the abiotic factors that influence productivity, kelp growth, community assemblages, and trophic structure (Dunton et al., 1982; Martin and Gallaway, 1994; Aumack et al., 2007).

Long-term and nearly continuous studies in the Boulder Patch have provided a valuable baseline dataset for documenting biological responses to regional climatic change. Assessments of benthic diversity based on years of intensive sampling have also provided species inventories

\footnotetext{
${ }^{1}$ Centre for Environmental and Molecular Algal Research (CEMAR), Biology Department, University of New Brunswick, PO Box 4400, Fredericton, New Brunswick E3B 5A3, Canada

${ }^{2}$ Corresponding author: Trevor.Bringloe@unb.ca

${ }^{3}$ Marine Science Institute, The University of Texas at Austin, Port Aransas, Texas 78373, USA

(C) The Arctic Institute of North America
} 
for infaunal and epilithic fauna (Dunton and Schonberg, 2000) and for benthic algae (Wilce and Dunton, 2014). These databases hold great promise for monitoring future changes in the Western Arctic since species from southern marine communities are expected to invade northward areas as perennial ice cover diminishes and isotherms retreat (Müller et al., 2009; Jueterbock et al., 2016). Accurate species inventories from multiple Arctic locations are critical to monitoring these changes as they relate to local flora and fauna. However, correct species identifications are critical to the accuracy and reliability of such baseline data. Marine algae can be extremely difficult to identify from morphology alone because of phenotypic plasticity, convergent evolution, and cryptic species diversity (Saunders, 2005). It is therefore important to corroborate morphological species identifications of marine algae with genetic data. Given the ecological importance of the Boulder Patch and its value for assessing shifts in benthic species composition and distribution, we sought to DNA barcode some of the flora reported by Wilce and Dunton (2014; DNA barcoding: Hebert et al., 2003; Saunders, 2005). This note represents updates to the Boulder Patch flora in light of DNA barcoding efforts. We feel these updates are important considering the ongoing ecological work at the Boulder Patch, the overall difficulty of obtaining specimens from Arctic locations, and the limited number of genetically verified species records for Arctic algae.

\section{METHODS}

We used scuba equipment to collect marine algae from several sites in the Boulder Patch area (Fig. 1) during two summer seasons (20-21 August 2014 and 20-25 July 2015). A portion of each specimen (approx. $1 \mathrm{~cm}^{2}$ ) was preserved in silica gel (not as pressed material) and brought back to the University of New Brunswick for DNA extraction (Saunders and McDevit, 2012) and amplification of the 5 end of the cytochrome c oxidase subunit I gene (COI-5P) in red algae (Saunders and Moore, 2013) and brown algae (Saunders and McDevit, 2012), and tufA in green algae (Saunders and Kucera, 2010). These specimens are currently stored at the University of New Brunswick. Partial ribulose-1, 5-biphosphate carboxylase large subunit $(r b c \mathrm{~L}-3 \mathrm{P})$ or full-length reads of $r b c \mathrm{~L}$ were amplified and sequenced for some specimens of brown algae for which COI-5P either did not amplify or was contaminated, and in specimens for which additional markers were needed to resolve taxonomy (Saunders and McDevit, 2012). Successful PCR products (see online Appendix 1: Table S1 for a list of specimens collected and Genbank accession numbers) were sent to Genome Quebec for forward and reverse sequencing. All genetic data were edited in Geneious version 8.0 (http://www.geneious.com; Kearse et al., 2012).

\section{RESULTS AND DISCUSSION}

We generated genetic data for two species of Chlorophyta, nine species of Ochrophyta, and nine species of Rhodophyta (Table 1). For 11 (55\%) of the species barcoded, genetic data were consistent with their name assignment based on morphology, though two of these remain only tentatively confirmed. The remaining $45 \%$ represented five species requiring name updates, two species of uncertain genetic assignment, and two species representing new records for the Boulder Patch (Table 1). We elaborate briefly on the updated species names below; however, we emphasize that these records may represent names misapplied by Wilce and Dunton (2014) or otherwise represent new records for the Boulder Patch (if both species identified occur in the area). In cases where sample sizes are large (e.g., > 20 specimens barcoded in Ahnfeltia borealis D.Milstein \& G.W.Saunders, Phycodrys fimbriata [Kuntze] Kylin, and Rhodomela lycopodioides f. flagellaris Kjellman), if the congener identified by Wilce and Dunton (2014) does occur in the Boulder Patch, it is likely a rare member of the flora.

Ulva prolifera O.F. Müller (previously identified as Ulva flexuosa Wulfen by Wilce and Dunton, 2014) is a species with genetically verified collections in Pacific, Arctic, and Atlantic basins but has only recently been DNA-barcoded from Canadian Arctic waters (Hudson Bay; Saunders and McDevit, 2013). Pylaiella washingtoniensis C.C. Jao (previously identified as Pylaiella littoralis [Linnaeus] Kjellman) is similarly reported in all three oceans and has again only recently been DNA-barcoded in the Arctic (Hudson Bay and Baffin Island; Saunders and McDevit, 2013; Küpper et al., 2016). Pylaiella littoralis is also reported from the Arctic, but occurs as three genetic groups, one in the Pacific and two in the Atlantic (one of the Atlantic groups is confirmed in the Arctic; Saunders and McDevit, 2013; Küpper et al., 2016). Substantial taxonomic work remains for species of Pylaiella.

In the red algae, Ahnfeltia borealis (previously identified as Ahnfeltia plicata [Hudson] Fries) is a recently described species occurring in Hudson Bay Arctic waters (Milstein and Saunders, 2012), and although A. plicata is reported from the Arctic, it is a rare member of sub-Arctic flora (only two genetically verified collections from Churchill, Manitoba; Saunders and McDevit, 2013) as compared to A. borealis. Phycodrys rubens (Linnaeus) Batters (updated to Phycodrys fimbriata) had been previously reported from the Arctic, but subsequent studies revealed that these specimens were assignable to $P$. fimbriata (Lindeberg and Lindstrom, 2010; Saunders and McDevit, 2013). Other genetically verified records of Phycodrys from Alaska include an $r b c \mathrm{~L}$ sequence from St. Lawrence Island that matches $P$. fimbriata (published as Phycodrys riggii N.L. Gardner; Lin et al., 2001), and P. riggii from Southeast Alaska (van Oppen et al., 1995). Bona fide Phycodrys rubens is also rare in the Atlantic provinces of Canada and the New England states (only nine genetically verified 


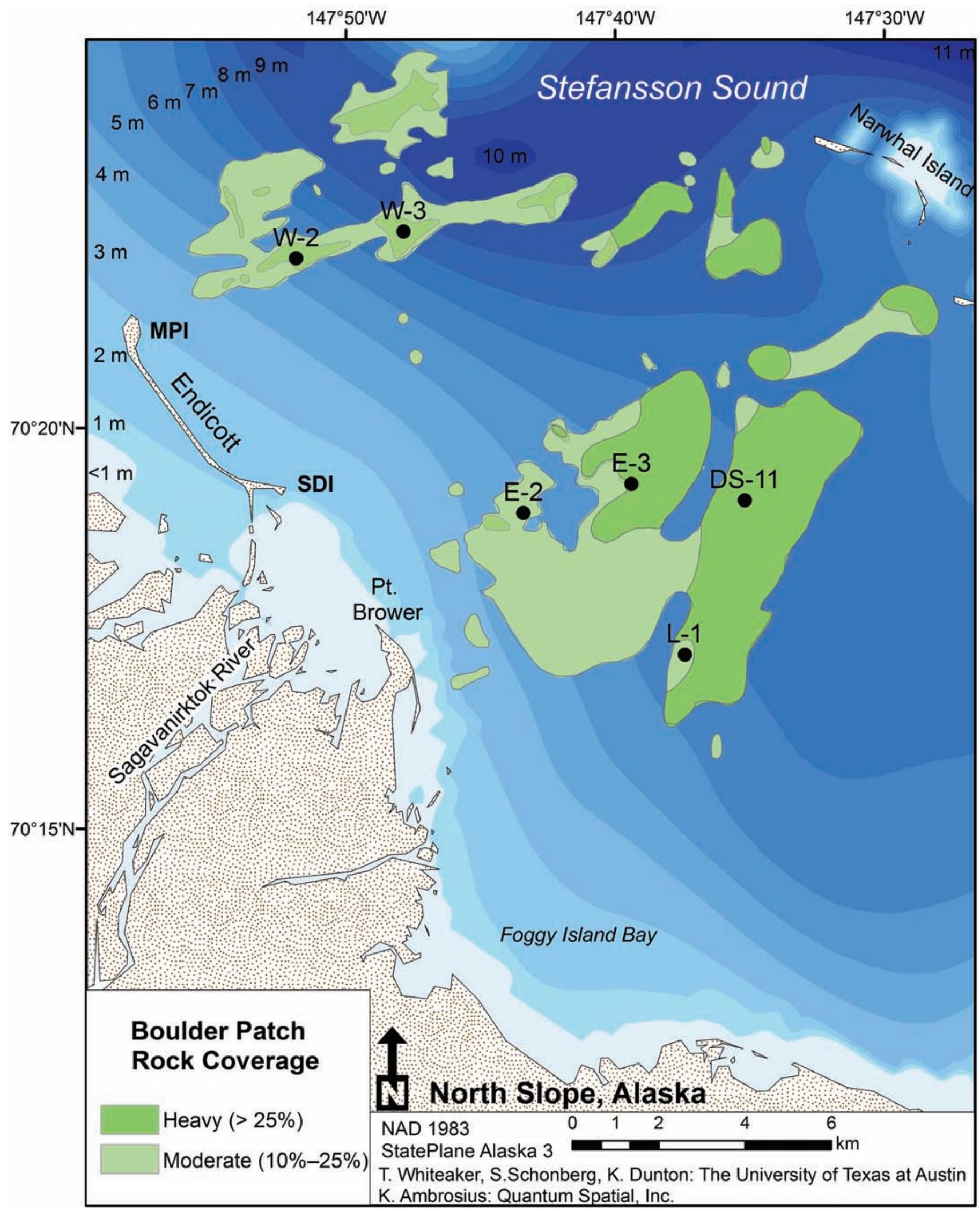

FIG. 1. Map of the Boulder Patch in Stefansson Sound off the North Slope of Alaska. Green shaded areas show the extent of the Patch as calculated from geological surveys conducted in 1980 and 1997 (Toimil and England, 1980; Coastal Frontiers and LGL, 1998). Light green represents zones where boulders cover $10 \%$ to $25 \%$ of the area, while dark green indicates zones with more than $25 \%$ boulder cover. 
TABLE 1. Summary of results from a DNA barcode survey of marine flora of the Boulder Patch in the Beaufort Sea off northern Alaska. See Figure 1 for site locations.

\begin{tabular}{|c|c|c|}
\hline Morphological listing & Collection site(s) & Molecular listing \\
\hline \multicolumn{3}{|l|}{ Chlorophyta: } \\
\hline Blidingia spp. & Narwhal Is. & $\begin{array}{l}\text { Confirmed (tentative): taxonomy of group needs study. Two species } \\
\text { listed in Wilce and Dunton (2014) with a single genetic group } \\
\text { confirmed (Blidingia } \text { sp._5GWS, } \mathrm{n}=1 \text { ). }\end{array}$ \\
\hline Ulva flexuosa Wulfen & Endicott Is. & Updated: Ulva prolifera O.F.Müller $(\mathrm{n}=2)$ \\
\hline \multicolumn{3}{|l|}{ Ochrophyta: } \\
\hline Alaria esculenta (Linnaeus) Greville & DS-11 & Confirmed $(n=3)$. \\
\hline $\begin{array}{l}\text { Battersia arctica (Harvey) Draisma, Prud'homme } \\
\quad \text { \& H.Kawai }\end{array}$ & E-2 & Confirmed $(n=1)$ \\
\hline Chaetopteris plumosa (Lyngbye) Kützing & E-3 & $\begin{array}{l}\text { Uncertain: cryptic complex }(\mathrm{n}=2) \text {; material needed from type locality, } \\
\text { but may represent a new species (recorded in Table S1 as } \\
\text { Chaetopteris sp. 2plumosa). }\end{array}$ \\
\hline Laminaria solidungula J.Agardh & DS-11, E-3, W-3 & Confirmed $(\mathrm{n}=7)$ \\
\hline Lithoderma fatiscens Areschoug & E-3 & $\begin{array}{l}\text { Confirmed (tentative; recorded in Table } \mathrm{S} 1 \text { as Lithoderma sp. 2GWS): } \\
\text { taxonomy of group needs study }(\mathrm{n}=1) \text {. }\end{array}$ \\
\hline Pylaiella littoralis (Linnaeus) Kjellman & Endicott Is. & Updated: Pylaiella washingtoniensis C.C.Jao $(\mathrm{n}=2)$ \\
\hline $\begin{array}{l}\text { Saccharina latissima (Linnaeus) C.E.Lane, } \\
\text { C.Mayes, Dreuhl, \& G.W.Saunders }\end{array}$ & DS-11, E-3 & Confirmed $(n=7)$ \\
\hline \multirow[t]{2}{*}{ Sorapion kjellmanii (Wille) Rosenvinge } & DS-11, E-3, W-3 & $\begin{array}{l}\text { Uncertain or new: Tilopteridalean sp._2GWS }(\mathrm{n}=4) \text {, which may } \\
\text { account for records of this species. Taxonomic work is needed. }\end{array}$ \\
\hline & E-3 & $\begin{array}{l}\text { Uncertain or new: Tilopteridalean sp._3GWS }(n=2) \text {, which may } \\
\text { account for records of this species. Taxonomic work is needed. }\end{array}$ \\
\hline \multicolumn{3}{|l|}{ Rhodophyta: } \\
\hline Ahnfeltia plicata (Hudson) Fries & DS-11, E-2, E-3, W-3 & Updated: Ahnfeltia borealis D.Milstein \& G.W.Saunders $(\mathrm{n}=23)$. \\
\hline Coccotylus truncatus (Pallas) M.J.Wynne \& J.N.Heine & DS-11, E-2, E-3, L-1, W-3 & Confirmed $(\mathrm{n}=31)$ \\
\hline Dilsea socialis (Postels \& Ruprecht) Perestenko & DS-11, E-3, W-3 & Confirmed $(\mathrm{n}=28)$ \\
\hline Odonthalia dentata (Linnaeus) Lyngbye & DS-11, E-3, W-2, W-3 & Confirmed $(\mathrm{n}=24)$ \\
\hline Phycodrys rubens (Linnaeus) Batters & DS-11, E-3, L-1, W-3 & Updated: Phycodrys fimbriata (Kuntze) Kylin $(\mathrm{n}=33)$ \\
\hline Phymatolithon foecundum (Kjellman) Düwel \& Wegeberg & DS-11, E-3 & $\begin{array}{l}\text { Confirmed }(\mathrm{n}=2) \text {. Current name Leptophytum foecundum (Kjellmann) } \\
\text { Adey. }\end{array}$ \\
\hline Phymatolithon tenue (Rosenvinge) Düwel \& Wegeberg & $\mathrm{W}-3$ & $\begin{array}{l}\text { Confirmed }(n=1) \text {. Considerable nomenclatural confusion surrounds } \\
\text { the correct name for this genetic group (Guiry and Guiry, 2017). }\end{array}$ \\
\hline \multirow[t]{2}{*}{ Rhodomela lycopodioides (Linnaeus) C.Agardh } & DS-11, E-3, W-3 & $\begin{array}{l}\text { Updated or new: Rhodomela lycopodioides f. flagellaris Kjellman } \\
\qquad(\mathrm{n}=29)\end{array}$ \\
\hline & E-2 & Updated or new: Rhodomela $\mathrm{cf}$. virgata Kjellman $(\mathrm{n}=1)$ \\
\hline
\end{tabular}

records, with all records of Phycodrys from the Canadian Arctic assignable to P. fimbriata; Saunders and McDevit, 2013). In short, Phycodrys rubens is relatively rare compared to $P$. fimbriata on Northwest Atlantic coasts, but it is common in the Northeast Atlantic, where $P$. fimbriata does not appear to occur. Rhodomela lycopodioides f. flagellaris (previously identified as Rhodomela lycopodioides [Linnaeus] C.Agardh) was previously reported only from the Arctic (Hudson Bay) along with several other genetic groups, including one that reportedly matches the features of Rhodomela lycopodioides sensu stricto (Saunders and McDevit, 2013). We did not, however, verify Rhodomela lycopodioides sensu stricto in our Boulder Patch collections. We did recover a second species of Rhodomela, Rhodomela cf. virgata Kjellman, that also occurs in Churchill (Saunders and McDevit, 2013) and has since been collected in the Northwest Atlantic (G.W. Saunders and T.B. Bringloe, unpubl. data). Considerable taxonomic work is needed in Rhodomela.

Substantial DNA barcoding work remains to be done in the Boulder Patch. If the same proportion of mismatches between morphological and DNA species identifications found in our sampling holds true for all other species on the list from Wilce and Dunton (2014), then nearly half of the remaining identifications may also be uncertain. A concerted effort to continue DNA barcoding in both freshly collected benthic algae and archived algal specimens from the Boulder Patch is a high priority. The long history of ecological study in the area (Dunton et al., 1982; Wilce and Dunton, 2014) has provided baseline information that will permit us to monitor impending ecological and species shifts due to climate change that may subsequently affect biodiversity. However, such monitoring requires accurate species lists, which highlights the urgent need to corroborate morphological identifications of marine algae with genetic data before such changes occur.

\section{ACKNOWLEDGEMENTS}

We thank the crew of the RV Proteus for their support of our diving efforts in Stefansson Sound and M. Bruce for her diving assistance in the collecting effort. We are grateful to A. Chan and T. Moore for their help with the generation of the molecular data. This project was funded by the Natural Sciences and Engineering Research Council of Canada, through a Post-Graduate Scholarship to T.T. Bringloe and a Discovery Grant to G.W. Saunders, and by the New Brunswick Innovation Foundation. 


\section{APPENDIX 1}

Table S1 is available as a supplementary file to the online version of this article at:

http://arctic.journalhosting.ucalgary.ca/arctic/index.php/ arctic/rt/suppFiles/4679/0

TABLE S1. List of specimens collected, in alphabetical order by species name, showing specimen ID, Genbank accession number, date sampled, and name and location of collection site.

\section{REFERENCES}

Aumack, C.F., Dunton, K.H., Burd, A.B., Funk, D.W., and Maffione, R.A. 2007. Linking light attenuation and suspended sediment loading to benthic productivity within an Arctic kelp-bed community. Journal of Phycology 43(5):853-863. https://doi.org/10.1111/j.1529-8817.2007.00383.x

Coastal Frontiers Corporation and LGL Ecological Research Associates, Inc. 1998. Liberty Development 1997-98 Boulder Patch survey. Final Report. Prepared for BP Exploration (Alaska) Inc. Anchorage.

Dunton, K.H., and Schonberg, S.V. 2000. The benthic faunal assemblage of the Boulder Patch kelp community. In: Truett, J.C., and Johnson, S.R., eds. The natural history of an Arctic oil field: Development and the biota. New York: Academic Press. 371-397. https://doi.org/10.1016/B978-012701235-3/50020-9

Dunton, K.H., Reimnitz, E., and Schonberg, S. 1982. An Arctic kelp community in the Alaskan Beaufort Sea. Arctic 35(4):465-484.

https://doi.org/10.14430/arctic2355

Guiry, M.D., and Guiry, G.M. 2017. Algaebase. World-wide electronic publication. Galway: National University of Ireland. http://www.algaebase.org

Hebert, P.D.N., Cywinska, A., Ball, S.L., and deWaard, J.R. 2003. Biological identifications through DNA barcodes. Proceedings of the Royal Society B, Biological Sciences 270(1512):313-321.

https://doi.org/10.1098/rspb.2002.2218

Jueterbock, A., Smolina, I., Coyer, J.A., and Hoarau, G. 2016. The fate of the Arctic seaweed Fucus distichus under climate change: An ecological niche modeling approach. Ecology and Evolution 6(6):1712-1724. https://doi.org/10.1002/ece3.2001

Kearse, M., Moir, R., Wilson, A., Stones-Havas, S., Cheung, M., Sturrock, S., Buxton, S., et al. 2012. Geneious Basic: An integrated and extendable desktop software platform for the organization and analysis of sequence data. Bioinformatics 28(12):1647-1649.

https://doi.org/10.1093/bioinformatics/bts199
Küpper, F.C., Peters, A.F., Shewring, D.M., Sayer, M.D.J., Mystikou, A., Brown, H., Azzopardi, E., et al. 2016. Arctic marine phytobenthos of northern Baffin Island. Journal of Phycology 52(4):532-549.

https://doi.org/10.1111/jpy.12417

Lin, S.-M., Fredericq, S., and Hommersand, M.H. 2001. Systematics of the Delesseriaceae (Ceramiales, Rhodophyta) based on large subunit rDNA and $r b c \mathrm{~L}$ sequences, including the Phycodryoideae, subfam. nov. Journal of Phycology 37(5):881-899. https://doi.org/10.1046/j.1529-8817.2001.01012.x

Lindeberg, M.R., and Lindstrom, S.C. 2010. Field guide to seaweeds of Alaska. University of Alaska Fairbanks: Alaska Sea Grant College Program.

Martin, L.R., and Gallaway, B.J. 1994. The effects of the Endicott Development Project on the Boulder Patch, an Arctic kelp community in Stefansson Sound, Alaska. Arctic 47(1):54-64. https://doi.org/10.14430/arctic1271

Milstein, D., and Saunders, G.W. 2012. DNA barcoding of Canadian Ahnfeltiales (Rhodophyta) reveals a new species Ahnfeltia borealis sp. nov. Phycologia 51(3):247-259.

https://doi.org/10.2216/11-40.1

Müller, R., Laepple, T., Bartsch, I., and Wiencke, C. 2009. Impact of oceanic warming on the distribution of seaweeds in polar and cold-temperate waters. Botanica Marina 52(6):617-638. https://doi.org/10.1515/BOT.2009.080

Reimnitz, E., and Ross, C.R. 1979. Lag deposits of boulders in Stefansson Sound, Beaufort Sea, Alaska. U.S. Geological Survey Open File Report 79-1205. 26 p. https://pubs.usgs.gov/of/1979/1205/report.pdf

Saunders, G.W. 2005. Applying DNA barcoding to red macroalgae: A preliminary appraisal holds promise for future applications. Philosophical Transactions of the Royal Society of London B, Biological Sciences 360(1462):1879-1888.

https://doi.org/10.1098/rstb.2005.1719

Saunders, G.W., and Kucera, H. 2010. An evaluation of $r b c L$, tufA, UPA, LSU and ITS as DNA barcode markers for the marine green macroalgae. Cryptogamie Algologie 31(4):487-528.

Saunders, G.W., and McDevit, D.C. 2012. Aquiring DNA sequence data from dried archival red algae (Florideophyceae) for the purpose of applying available names to contemporary genetic species: A critical assessment. Botany 90(3):191 - 203. https://doi.org/10.1139/B11-079

- 2013. DNA barcoding unmasks overlooked diversity improving knowledge on the composition and origins of the Churchill algal flora. BMC Ecology 13(9). 23 p.

https://doi.org/10.1186/1472-6785-13-9

Saunders, G.W., and Moore, T.E. 2013. Refinements for the amplification and sequencing of red algal DNA barcode and RedToL phylogenetic markers: A summary of current primers, profiles and strategies. Algae 28(1):31-43. https://doi.org/10.4490/algae.2013.28.1.031

Toimil, L.J., and England, J.M. 1980. Investigation of rock habitats and sub-seabed conditions, Beaufort Sea, Alaska. Anchorage: Harding Lawson Associates. 
van Oppen, M.J.H., Draisma, S.G.A., Olsen, J.L., and Stam, W.T. 1995. Multiple trans-Arctic passages in the red alga Phycodrys rubens: Evidence from nuclear rDNA ITS sequences. Marine Biology 123(1):179-188.

https://doi.org/10.1007/BF00350338
Wilce, R.T., and Dunton, K.H. 2014. The Boulder Patch (North Alaska, Beaufort Sea) and its benthic algal flora. Arctic 67(1):43-56.

https://doi.org/10.14430/arctic4360 